\title{
DIETARY ECOLOGY OF THE COMMON SUN SKINK Eutropis multifasciatus (Kuhl, 1820) IN THUA THIEN-HUE PROVINCE, VIETNAM
}

\author{
Ngo Dac Chung ${ }^{1}$, Ngo Van Binh ${ }^{2 *}$, Nguyen Thi Truong Thi $^{3}$ \\ ${ }^{1}$ College of Education, Hue University, Hue, Vietnam \\ ${ }^{2}$ National Cheng Kung University, Tainan City 70101, Taiwan, *biological99999@ gmail.com \\ ${ }^{3}$ Quang Tri Teacher Training College, Vietnam
}

\begin{abstract}
Eutropis multifasciatus (Kuhl, 1820) is a common species in Vietnam, the knowledge of ecology of this terrestrial viviparous skink is still poorly known. In this study, we focused on the feeding ecology of E. multifasciatus to understand spatial, temporal, and sexual variations in the dietary composition of E. multifasciatus. A total of 323 food items, viz. 288 animal items and 29 plant items were found in 176 stomachs of skinks. The most numerous prey items of E. multifasciatus were spiders, insect larvae, grasshoppers, and crickets (with an importance index of 51.4\%). The total volume of food items consumed by males was greater than that consumed by females $(P=0.028)$, and the volume of food items in the dry season was greater than in the rainy season $(P=0.002)$. The rarefaction curves for prey category richness were higher in females than in males for both occurrence frequency and count of items.
\end{abstract}

Keywords: Eutropis multifasciatus, feeding ecology, prey items, sun skink.

\section{INTRODUCTION}

Central Vietnam belongs to the Indo-Burma region, that is considered to be one of the biodiversity hotspots of the world [6]. There are more than 10,000 recognized species of worldwide distribution [12], of those reptiles are an important component of the global biodiversity and play a significant role in natural ecosystems. They inhabit both aquatic and terrestrial habitats and additionally, food habits of lizards offer essential information for constructing food webs $[2,9]$. Dietary variation can provide additional insights for our understanding of life history features, resource and habitat use, and interspecific interactions of species [7]. However, the vast majority of studies on lizards have been conducted on fewer than $10 \%$ of extant species [9].

Information on the feeding ecology of Eutropis multifasciatus (formerly Eutropis multifasciata), a terrestrial viviparous skink, is still lacking even though its terrestrial habitats have been determined as important to herpetological conservation programs $[9,13]$. Previous studies of lizards in central Vietnam have focused primarily on taxonomy. While several studies of the dietary ecology of lizards have been completed, only a few species were included. Thus, studies of feeding ecology, including an estimate of spatiotemporal and sexual variations in the dietary composition of E. multifasciatus, are valuable to gain insight into their ecology and population status and to inform management and conservation plans for this species.

In this study, we investigated the dietary ecology of E. multifasciatus in the mountain and midland regions of Thua Thien-Hue province. We evaluated variations in the composition of prey items of E. multifasciatus from different geographic areas, seasons, and sexual groups. In addition, the correlation in size between predator and prey was also examined. We tested the hypothesis that individuals sampled from different geographic areas, different seasons, and sexes differed in prey consumption. The prediction is that the dietary composition of E. multifasciatus would differ among seasons and between sexes because mouth sizes of skinks (width and gape) are positively correlated with prey sizes found in their stomach $[9,13]$.

\section{MATERIALS AND METHODS}

\section{Sampling}

Field surveys were conducted from October 
2013 to May 2014, three times per month, for collecting stomach contents of E. multifasciatus from the following localities in Thua Thien-Hue province (fig. 1): (1) Hong Van $\left(16^{\circ} 22^{\prime} 54^{\prime \prime} \mathrm{N}\right.$ $\left.107^{\circ} 06^{\prime} 17^{\prime \prime E}\right) ; \quad$ (2) Son Thuy $\left(16^{\circ} 15^{\prime} 10^{\prime \prime} \mathrm{N}-\right.$ $\left.107^{\circ} 16^{\prime} 08^{\prime \prime} \mathrm{E}\right)$; (3) Huong Lam $\left(16^{\circ} 07^{\prime} 47^{\prime \prime N}\right.$ $\left.107^{\circ} 21^{\prime} 07^{\prime \prime E}\right)$; (4) Huong Son $\left(16^{\circ} 12^{\prime} 21^{\prime \prime N}\right.$ $\left.107^{\circ} 38^{\prime} 29^{\prime \prime} \mathrm{E}\right)$; and Thuong Lo $\left(16^{\circ} 08^{\prime} 15^{\prime \prime} \mathrm{N}-\right.$ $\left.107^{\circ} 44^{\prime} 27^{\prime \prime} \mathrm{E}\right)$. Contents of 176 stomachs (82 males and 94 females) of E. multifasciatus were collected for prey item analysis. Stomach contents were collected in approximately equal proportions between seasons, 86 stomachs in the wet season (October to January) and 90 stomachs in the dry season (February to May).

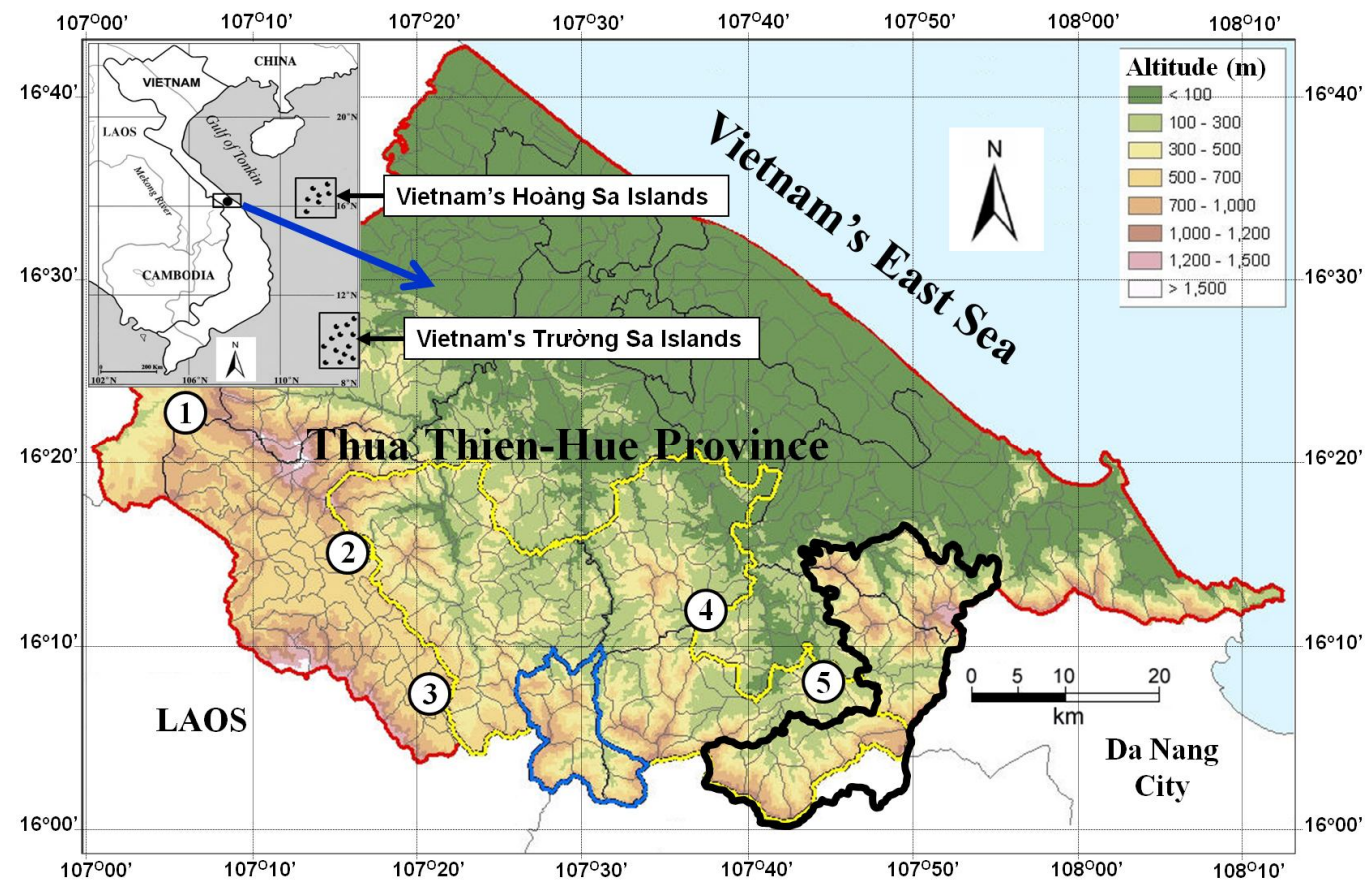

Figure 1. Map showing the survey sited in Thua Thien-Hue province, Vietnam: (1) Hong Van, (2) Son Thuy, (3) Huong Lam, (4) Huong Son, and (5) Thuong Lo.

The bulk of our search effort was carried out during daytime between 08:00 and 16:00 when the skinks are active, particularly in sunny days. Specimens were collected by hand, rods, and pitfall traps along survey transects, each transect approximately $3 \mathrm{~km}$ in length, in different habitat types from villages, open areas, riparian forest, plantations, and fields (e.g., ricefields, cornfields, and sugar-cane fields). Each captured skink was kept in a labelled bag.

\section{Measurements and statistical analysis}

In the laboratory, we euthanized skinks with a solution of Chloroform the same day that they were collected. Measurements were taken with digital calipers (Mitutoyo, Japan) to the nearest $0.01 \mathrm{~mm}$ : snout-vent length (SVL), tail length (TL), and mouth width (MW). Body mass (BM) was measured with an electronic balance (Prokits, Taiwan) to the nearest $0.1 \mathrm{~g}$. We separated and fixed in 10\% formalin stomach contents within two days prior to the analyses. Prey items were identified to the lowest possible taxonomic level (mostly to the order but sometimes to the family level). We follow the keys and descriptions in Pechenik (2014) [8] for the identification of insect groups and Johnson \& Triplehorn (2005) [3] for the nomenclature. Plant materials were considered food categories of E. multifasciatus, remains of abiotic 
materials (e.g., sand, stones, and plastic parts) were excluded from the analyses.

The volume $(\mathrm{V})$ of food items by using the formula for a prolate spheroid (with $\pi=3.14159$; Biavati et al., 2004; Ngo et al., 2014) [1, 7]:

$$
\mathrm{V}=\frac{4 \pi}{3} \times\left(\frac{\text { length }}{2}\right) \times\left(\frac{\text { width }}{2}\right)^{2}
$$

The length (head to thorax) and width (at widest centrally located section) of the body of each prey item was taken.

The index of relative importance (IRI) was used to determine the importance of each food category. This index provides a more informed estimation of food item consumption than any of the three components alone by using the following formula [1, 7]:

$$
\mathrm{IRI}=(\% \mathrm{~F}+\% \mathrm{~N}+\% \mathrm{~V}) / 3
$$

Where $F$ is frequency of stomachs that contain a particular food item, $N$ is the total number of the food item in relation to all food items, and $V$ is the total volume of the food item.

To estimate heterogeneity of food items among localities and between sexes, the Simpson's index of diversity (Simpson, 1949) [11] was used:

$$
D=\Sigma\left[n_{i}\left(n_{i}-1\right)\right] /[N(N-1)]
$$

Where $n_{\mathrm{i}}$ is the number of food items in the $i^{\text {th }}$ taxon category and $N$ is the total number of food items, $S$ is the number of prey taxa in the sample [5].

We also adopted the reciprocal Simpson's heterogeneity index, 1/D (Simpson's reciprocal index), to calculate the dietary breadth of $E$. multifasciatus.

The Shannon's index of evenness was used for estimating evenness:

$$
\mathrm{J}^{\prime}=\mathrm{H}^{\prime} / \mathrm{H}_{\max }=\mathrm{H}^{\prime} / \mathrm{ln} \mathrm{S}
$$

The maximum diversity $\left(\mathrm{H}_{\max }\right)$ that could possibly occur that would be found in a situation where all taxa had equal abundance $\left(\mathrm{H}^{\prime}=\mathrm{H}_{\max }=\ln \mathrm{S}\right), S$ is the total number of prey taxa, and $H^{\prime}$ is the Shannon index of taxon diversity. In there, the value of $\mathrm{H}^{\prime}$ is calculated from the equation:

$$
\mathrm{H}^{\prime}=-\Sigma p_{i} \times \ln p_{i}
$$

Where the quantity $p_{i}$ is the proportion of total food items belonging to the $i^{\text {th }}$ taxon for the total food items of the sample [5].

The rarefaction method were used to estimate the diversity of diet between males and females. We estimated expected prey taxon accumulation curves [4] and interpolated their 95\% confidence intervals using the Software for Ecological Methodology (New York, USA). We standardized all samples using the rarefaction method from the diet of male and female skinks to a same sample size using the modified algorithm by Simberloff (1972) [10] as follows:

$$
E\left(S_{n}\right)=\sum_{i=1}^{S}\left[1-\frac{\left(\begin{array}{c}
N-N_{i} \\
n
\end{array}\right)}{\left(\begin{array}{c}
N \\
n
\end{array}\right)}\right]
$$

Where $E\left(S_{n}\right)$ is the expected number of prey taxa in a random sample of $n$ prey items, $S$ is the total number of prey taxa in the entire collection from stomach contents, $N_{i}$ is the number of prey items in the $i^{\text {th }}$ taxon, $N$ is the total number of prey items in the entire collection, $n$ is the value of sample size (number of prey items) chosen for standardization ( $n \leq$ $N)$, and $\left(\begin{array}{l}N \\ n\end{array}\right)=N ! / n !(N-n)$ ! is the number of combinations of $n$ prey items that can be chosen from a set of $N$ prey items. For the variance of the expected number of prey taxa, var $\left(S_{n}\right)$, in the random sample of $n$ prey items in this present study was calculated following Krebs (1999) [4].

Correlation in size between skink and prey items was analyzed with the software STATISTICA 10.0 (StatSoft, Tulsa, Oklahoma, USA) for Windows 7 with the significance level to $P \leq 0.05$. We used the one-way analysis of variance (ANOVA) to test the number of stomachs collected, prey size (length and width), and volume between seasons, localities, and sexes. We used the multivariate analysis of variance (MANOVA) to examine the effects of season and site on the volumes of major food items. We $\log _{10}$-transformed data on mean size of food items per skink to normalize distributions prior to statistical analyses. To determine if size differences of food items between sexes were 
Ngo Dac Chung et al.

due to differences in size of skinks (SVL), we first calculated residuals using $\log _{10}(\mathrm{SVL})$ to remove the effect of SVL, then performed an analysis of covariance (ANCOVA) on the residuals with SVL as a covariate. All data are presented as mean \pm standard deviation (SD) unless otherwise noted.

\section{RESULTS AND DISCUSSION}

The number of collected specimens was not significantly different between seasons (ANOVA, $\left.\quad F_{1,39}=0.321, \quad P=0.574\right), \quad$ among localities $\left(F_{4,39}=0.262, P=0.904\right)$, and between sexes $\left(F_{1,15}=0.912, P=0.357\right)$. About $25 \%(44$ stomachs) of the 176 stomachs of $E$. multifasciatus were empty. We identified a total of 323 food items (288 animal items, 29 plant items, and 6 unidentified items) in the stomach of E. multifasciatus (table 1). The food items in females (189 items) were significantly higher than in males (134 items; ANOVA, $\left.F_{1,131}=1.751, P=0.189\right)$. The number of food items between the rainy season (167 items) and the dry season (156 items) was significantly different $\left(F_{1,131}=4.422, P=0.037\right)$. In terms of prey categories, remains of 15 invertebrate groups and one vertebrate group (small skinks) were determined (see table 1). The mean number of food items per individual (mean \pm SD) was $1.84 \pm 1.81$ (min-max: 0-8, $\mathrm{n}=176$ ). Mean food item length was $27.04 \pm 21.57 \mathrm{~mm}$ (minmax: 2.16-100.7, $n=323$ ), mean food item width was 9.67 $\pm 6.09 \mathrm{~mm}$ (min-max: 0.11-33.1, $\mathrm{n}=323$ ), and average volume of food items was 446.62 $\pm 457.19 \mathrm{~mm}^{3}$ (min-max: 0.03-2724.23, $\mathrm{n}=323)$.

Table 1. Dietary composition of Eutropis multifasciatus ( $n=132$ stomach contents) in Thua ThienHue province: $\mathrm{F}=$ frequency of occurrence, $\mathrm{N}=$ number of items, $\mathrm{V}=$ volume $\left(\mathrm{mm}^{3}\right)$, IRI=index of relative importance of each taxon. *Number of stomachs containing food items

\begin{tabular}{|c|c|c|c|c|c|c|c|}
\hline \multirow{2}{*}{ Prey category } & \multicolumn{2}{|c|}{ Frequency $(\mathrm{F})$} & \multicolumn{2}{|c|}{ Count $(\mathrm{N})$} & \multicolumn{2}{|c|}{ Volume (V) } & \multirow{2}{*}{ IRI } \\
\hline & $\mathrm{F}^{*}$ & $\% \mathrm{~F}$ & $\mathrm{~N}$ & $\% \mathrm{~N}$ & $\mathrm{~V}$ & $\% \mathrm{~V}$ & \\
\hline Araneae & 35 & 14.00 & 48 & 14.86 & 7710.59 & 13.08 & 13.98 \\
\hline Blattodea & 7 & 2.80 & 7 & 2.17 & 1832.10 & 3.11 & 2.69 \\
\hline Coleoptera & 15 & 6.00 & 17 & 5.26 & 3829.04 & 6.50 & 5.92 \\
\hline Diptera & 5 & 2.00 & 6 & 1.86 & 275.14 & 0.47 & 1.44 \\
\hline Hemiptera & 7 & 2.80 & 12 & 3.72 & 119.96 & 0.20 & 2.24 \\
\hline Hymenoptera & 15 & 6.00 & 16 & 4.95 & 2704.69 & 4.59 & 5.18 \\
\hline Insect larvae & 27 & 10.80 & 35 & 10.84 & 7226.59 & 12.26 & 11.31 \\
\hline Isoptera & 10 & 4.00 & 13 & 4.02 & 2344.52 & 3.98 & 4.01 \\
\hline Lepidoptera & 5 & 2.00 & 6 & 1.86 & 730.71 & 1.24 & 1.71 \\
\hline Odonata & 1 & 0.40 & 1 & 0.31 & 59.48 & 0.10 & 0.27 \\
\hline Orthoptera & 58 & 23.20 & 84 & 26.01 & $17,142.88$ & 29.08 & 26.11 \\
\hline Lumbriculida & 11 & 4.40 & 12 & 3.72 & 4574.11 & 7.76 & 5.29 \\
\hline Chilopoda & 4 & 1.60 & 4 & 1.24 & 734.85 & 1.25 & 1.36 \\
\hline Gastropoda: Achatinidae & 17 & 6.80 & 20 & 6.19 & 4500.15 & 7.63 & 6.88 \\
\hline Reptilia: Scincidae & 7 & 2.80 & 7 & 2.17 & 1962.13 & 3.33 & 2.77 \\
\hline Plant materials & 22 & 8.80 & 29 & 8.98 & 2794.74 & 4.74 & 7.51 \\
\hline Unidentified & 4 & 1.60 & 6 & 1.86 & 405.18 & 0.69 & 1.38 \\
\hline
\end{tabular}

The total dietary breadth of E. multifasciatus was 8.17 with a Shannon's index of evenness of 0.85 . The broadest dietary breadth was found at the Huong Lam area (9.74) with an index of evenness of 0.91, whereas the narrowest dietary breadth was found at the Hong Van area (6.11) with an index of evenness of 0.81 (table 2). Two populations of skinks from Son Thuy and Huong Lam areas consumed food items in 14 types, while the population at the Hong Van only consumed 12 food types, and the highest number of food categories were found at the Thuong Lo area (15 types). All five populations 
consumed spiders, stinkbugs, ants, larvae of and plant types, with a combined numeric insects, grasshoppers and crickets, earthworms, percentage of about $73 \%$ (table 2).

Table 2. Comparison of the dietary breadth, index of evenness, and occurrence of prey items of Eutropis multifasciatus in Thua Thien-Hue province (HV=Hong Van, ST=Son Thuy, HL=Huong Lam, HS=Huong Son, TL=Thuong Lo).

\begin{tabular}{lcccccc}
\hline \multirow{2}{*}{ Prey and indices } & \multicolumn{5}{c}{ Location } & \multirow{2}{*}{ Total } \\
\cline { 2 - 6 } & HV & ST & HL & HS & TL & \\
\hline Araneae & 19.6 & 12.7 & 11.4 & 17.7 & 13.9 & 14.9 \\
Blattodea & 1.8 & 3.2 & 4.3 & - & 1.4 & 2.2 \\
Coleoptera & 3.6 & 11.1 & 2.9 & 9.7 & - & 5.3 \\
Diptera & 1.8 & 1.6 & - & - & 5.6 & 1.9 \\
Hemiptera & 5.4 & 1.6 & 8.6 & 1.6 & 1.4 & 3.7 \\
Hymenoptera & 1.8 & 1.6 & 8.6 & 8.1 & 4.2 & 5.0 \\
Insect larvae & 17.9 & 3.2 & 10.0 & 11.3 & 12.5 & 10.8 \\
Isoptera & - & 1.6 & 8.6 & 4.8 & 4.2 & 4.0 \\
Lepidoptera & - & - & 4.3 & 1.6 & 2.8 & 1.9 \\
Odonata & - & 1.6 & - & - & - & 0.3 \\
Orthoptera & 30.4 & 30.2 & 24.3 & 21.0 & 25.0 & 26.0 \\
Lumbriculida & 1.8 & 1.6 & 4.3 & 6.5 & 4.2 & 3.7 \\
Chilopoda & 1.8 & - & - & 3.2 & 1.4 & 1.2 \\
Gastropoda: Achatinidae & 7.1 & 15.9 & 2.9 & - & 5.6 & 6.2 \\
Reptilia: Scincidae & - & 1.6 & 1.4 & 3.2 & 4.2 & 2.2 \\
Plant materials & 7.1 & 12.7 & 5.7 & 9.7 & 9.7 & 9.0 \\
Unidentified & - & - & 2.9 & 1.6 & 4.2 & 1.9 \\
\hline Total categories & $\mathbf{1 2}$ & $\mathbf{1 4}$ & $\mathbf{1 4}$ & $\mathbf{1 3}$ & $\mathbf{1 5}$ & $\mathbf{1 7}$ \\
Niche breadth & 6.11 & 6.62 & 9.74 & 9.22 & 9.03 & 8.17 \\
Index of evenness & 0.81 & 0.79 & 0.91 & 0.89 & 0.87 & 0.85 \\
\hline
\end{tabular}
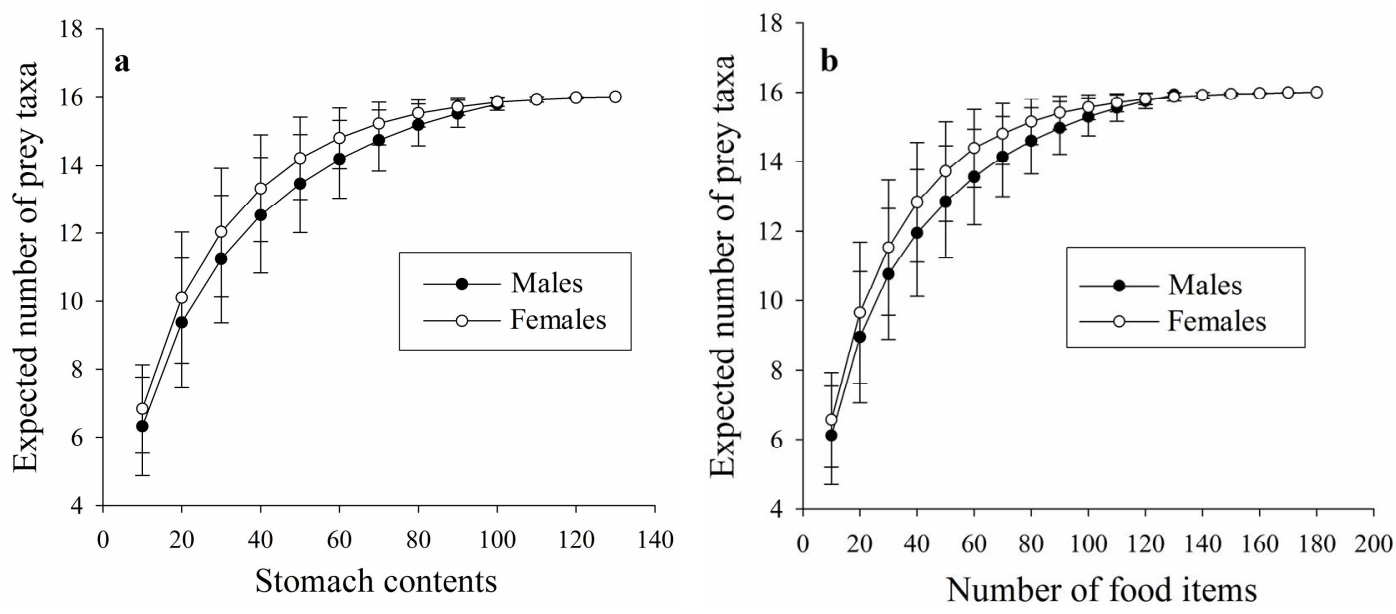

Figure 2. Expected prey-taxon accumulation curves based on occurrence frequency of prey (a) and count of food items (b) consumed by Eutropis multifasciatus. Circles represent the expected mean values and the graphs show the 95\% confidence intervals for males (filled circles) and females (open circles). 
The number of prey categories was the same in males and in females (16). However, the diversity index of consumed prey and the evenness index were significantly higher in females (diversity index of 9.12 with an evenness index of 0.88) than in males (diversity index of 6.72 with an evenness index of 0.81). Prey category richness was also higher for females than for males in both occurrence frequency (fig. 2a) and number of items (fig. 2b). Female skinks have higher rarefaction curves (prey category richness per fixed number of individuals is higher in this sex). One essential problem in community ecology that frequently appears in comparing the samples of communities is that they are based on different sample sizes (sample size of prey items). In fact, we do not know immediately which community has higher species richness if we only base our estimates on the number of species and the number of individuals between two communities. One way to resolve this problem is to standardize all samples from different communities to a common sample size of the same number of individuals [4].

The most abundant prey categories (i.e. IRI $\geq$ 11.3) of E. multifasciatus were spiders, insect larvae, and grasshoppers and crickets, accounting for $48.0 \%$ of occurrence frequency, $51.7 \%$ of the number of prey items, and $54.4 \%$ of the total volume, with an index of relative importance of $51.4 \%$ (Table 1). Based on the importance index of the diet of E. multifasciatus, such as Araneae, insect larvae, Orthoptera, Coleoptera, Hymenoptera, Lumbriculida, Achatinidae, and plant materials, were the most important food items (i.e. IRI $\geq$ 5.18). Using two-factor MANOVA to examine the effects of season and site on the variance in the volumes of major food items (i.e. IRI $>5.1$ ) revealed that the season factor was significantly different (Wilks' $\left.\lambda=0.532, F_{8,22}=2.421, P=0.048\right)$. The volume of major food items, however, did not vary among the sites (Wilks' $\lambda=0.422, F_{32,82}=0.681, P=0.887$ ) or by season-site interaction (Wilks' $\lambda=0.261$, $F_{32,82}=1.227, P=0.318$ ).

The mean volume of food items per male individual was $493.2 \pm 492.4 \mathrm{~mm}^{3}$, ranging from 2.85-2724.23 $\mathrm{mm}^{3}$ (total volume of $29,594.1$ $\mathrm{mm}^{3}, \mathrm{n}=82$ ), compared to $407.8 \pm 425.2 \mathrm{~mm}^{3}$ per female, ranging from $0.03-2010.44 \mathrm{~mm}^{3}$ (total volume of $\left.29,359.2 \mathrm{~mm}^{3}, \mathrm{n}=94\right)$. The size of prey items (length and width) and volume of food items consumed by males comparing to females were not significantly different (ANOVA, length: $F_{1,131}=1.651, P=0.201$; width: $F_{1,131}=0.212, \quad P=0.644$; volume: $F_{1,131}=1.142$, $P=0.287)$. However, when SVL was taken into account as a covariate, volume of food items consumed by male skinks were significantly greater than that of female skinks with $\log _{10}(\mathrm{SVL})$ as a covariate (ANCOVA, $\left.F_{1,131}=4.921, P=0.028\right)$.

The total volume of food items in the dry season was greater than in the rainy season. Average volume per food item in the rainy season was $418.2 \pm 556.2 \mathrm{~mm}^{3}$, ranging from $0.03-2724.23 \mathrm{~mm}^{3}$ (total volume of $25,092.7$ $\mathrm{mm}^{3}, \mathrm{n}=86$ ). In comparison, it was $470.3 \pm 356.8$ $\mathrm{mm}^{3}$ in the dry season, ranging from 2.85$1552.02 \mathrm{~mm}^{3}$ (total volume of $33,860.6 \mathrm{~mm}^{3}$, $\mathrm{n}=90$ ). The size of prey items (length and width) and volume of food items between seasons were significantly different (ANOVA, length: $F_{1,131}=4.451, \quad P=0.037$; width: $F_{1,131}=19.911$, $P<0.0001$; volume: $F_{1,131}=10.521, \quad P=0.002$ ). The total volume of food items from study sites were 13,990.9 $\mathrm{mm}^{3}$ (63 items); 12,203.4 $\mathrm{mm}^{3}$ (71 items); 11,459.7 $\mathrm{mm}^{3}$ (58 items); 10,697.2 $\mathrm{mm}^{3}$ (72 items) and $10,602.2 \mathrm{~mm}^{3}$ (59 items) in Son Thuy, Huong Lam, Huong Son, Thuong Lo and Hong Van areas, respectively. The total volume of food items consumed by skinks was not significantly different among localities (ANOVA, $F_{4,322}=0.573, P=0.682$ ).

The volume of food items consumed by skinks was positively correlated with SVL ( $r=0.247, F_{2,130}=8.412, P=0.004$; figure $3 \mathrm{a}$ ) and MW ( $r=0.202, F_{2,130}=5.521, P=0.02$; figure $3 b$ ). Both SVL and MW are considered the predictor variables in the feeding ecology of lizards, because there were strong positive correlations between the morphological measurements (SVL and MW: $r=0.798, P<0.0001$; $\mathrm{MW}$ and BM: $r=0.739, P<0.0001$; SVL and BM: $r=0.774$, $P<0.0001)$. The results of multiple regressions for possible effects of temperature, moisture, and precipitation on the size of prey items 
(length and width), number of items, and volume were significant (prey length: $r^{2}=0.302$; $F_{3,131}=18.482, P<0.0001$; prey width: $r^{2}=0.215$;

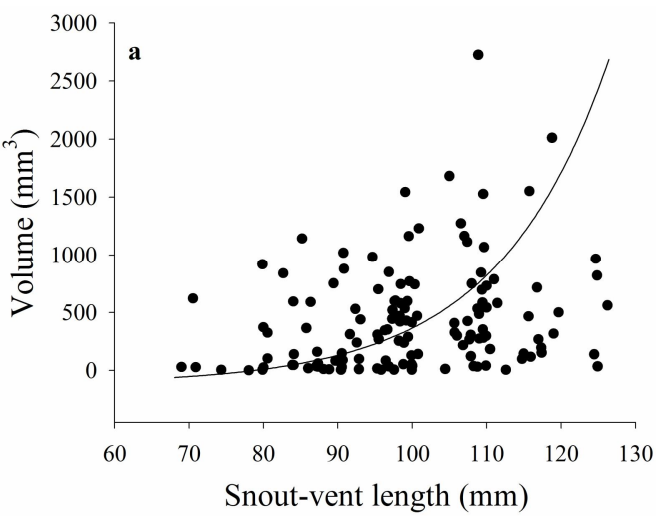

$F_{3,131}=11.721, P<0.0001$; item count: $r^{2}=0.258$; $F_{3,131}=14.851, \quad P<0.0001$; prey volume: $r^{2}=$ $\left.0.182 ; F_{3,131}=9.512, P<0.0001\right)$.

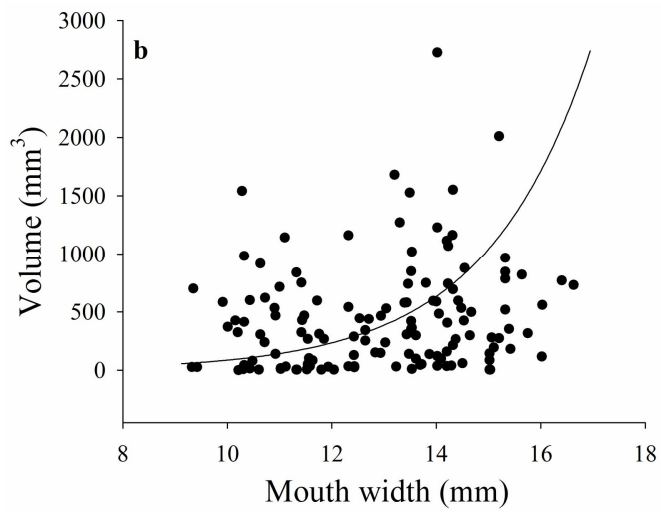

Figure 3. Relationships between the volume of consumed prey categories and (a) snout-vent length, and (b) mouth width of Eutropis multifasciatus

\section{CONCLUSION}

The Common Sun Skink is an omnivorous species, the most common prey items of this species were spiders, insect larvae, and grasshoppers and crickets, with a combined importance index of 51.4\%. Simpson's index of diversity and Shannon's index of evenness were higher in females than in males. Prey category richness was higher in females than in males in both occurrence frequency and number of items. Temperature, moisture, and precipitation were significantly correlated with the size of prey items, number of items, and volume consumed by skinks.

Acknowledgements: This research was funded by Vietnam's National Foundation for Science and Technology Development (NAFOSTED, Grant No. 106-NN.05-2013.18). We thank Dr. Paterson for comments.

\section{REFERENCES}

1. Biavati G. M., Wiederhecker H. C., Colli G. R., 2004. Diet of Epipedobates flavopictus (Anura: Dendrobatidae) in a neotropical savanna. J. Herpetol., 38(4): 510-518.

2. Elton C. S., 2001. Animal Ecology. University of Chicago Press, Chicago, Illinois, USA, 209 p.
3. Johnson N. F., Triplehorn C. A., 2005. Borror and Delong's Introduction to the Study of Insects. Thomson Learning, Inc., Belmont, California, USA, 864 p.

4. Krebs C. J., 1999. Ecological Methodology. Addison Wesley Longman, Menlo Park, California, USA, 620 p.

5. Magurran A. E., 2004. Measuring Biological Diversity. Blackwell Science, Malden, Massachusetts, USA, 264 p.

6. Myers N. R., Mittermeier A., Mittermeier C. G., Fonseca G. B., Kent J., 2000. Biodiversity hotspots for conservation priorities. Nature, 403(6772): 853-858.

7. Ngo B. V., Lee Y.-F., Ngo C. D., 2014. Variation in dietary composition of granular spiny frogs (Quasipaa verrucospinosa) in central Vietnam. Herpetol. J., 24(4): $245-$ 253.

8. Pechenik J., 2014. Biology of the Invertebrates - Seven Edition. McGrawHill, New York, New York, USA, 624 p.

9. Reilly S. M., McBrayer L. D., Miles D. B., 2007. Lizard Ecology. Cambridge University Press, Cambridge, UK, 531 p.

10. Simberloff D., 1972. Properties of the rarefaction diversity measurement. Am. 
Nat., 106(494): 414-418.

11. Simpson E. H., 1949. Measurement of diversity. Nature, 163(4148): 688.

12. Uetz P., Hošek J. (eds.), 2014. The Reptile
Database. Available at: http://www.reptiledatabase.org. Last accessed July 8, 2014.

13. Vitt L. J., Caldwell J. P., 2009. Herpetology. Academic Press, Burlington, Massachusetts, USA, $720 \mathrm{p}$.

\title{
SINH THÁI HOCC DINH DỮ̃̃NG CỦA LOÀI THẰN LÀ̀N BÓNG HOA Eutropis multifasciatus (Kuhl, 1820) Ở TỈNH THÙAA THIÊN-HUẾ, VIẸT NAM
}

\author{
Ngô Đắc Chứng ${ }^{1}$, Ngô Văn Bình ${ }^{2}$, Nguyễn Thị Trường Thi ${ }^{3}$ \\ ${ }^{1}$ Trường Đại học Sư phạm, Đại học Huế \\ ${ }^{2}$ Đại học Quốc gia Cheng Kung, Đài Loan \\ ${ }^{3}$ Trường Cao đẳng Sư phạm Quảng Trị
}

\section{TóM TẮT}

Thằn lằn bóng hoa, Eutropis multifasciatus là một loài phổ biến ở Việt Nam, tuy nhiên, sự hiểu biết về sinh thái học của loài có hình thức noãn thai sinh này còn ít. Trong nghiên cứu này, chúng tôi tập trung phân tích sinh thái học dinh dưỡng của $E$. multifasciatus nhằm tìm hiểu về những biến đổi trong không gian, thời gian và giới tính trong thành phần dinh dưỡng của chúng. Tổng cộng gồm 323 loại thức ăn, trong đó 288 loại có nguồn gốc động vật (15 con mồi) và 29 loại có nguồn gốc thực vật được tìm thấy trong 176 dạ dày của E. multifasciatus. Các loại con mồi gồm gặp nhiều nhất là nhện, âu trùng của côn trùng, châu chấu và dế (với một chỉ số quan trọng chiếm 51,4\%). Thể tích tổng số của các loại thức ăn đã tiêu thụ bởi các con đực lớn hơn thể tích tổng số của các loại thức ăn đã tiêu thụ bởi các con cái $(P=0,028)$, thể tích tổng số của các mục thức ăn trong mùa khô lớn hơn mùa mưa $(P=0,002)$. Các đường cong đối với sự phong phú của các loại con mồi được kỳ vọng ở các con cái là cao hơn so với các con đực cho cả hai tần số dạ dày và số lượng mục thức ăn. Tù khóa: Eutropis multifasciatus, con mồi, sinh thái dinh dưỡng, thằn lằn bóng.

Ngày nhận bài: 12-4-2014 